\title{
PERENCANAAN STRUKTUR RANGKA BAJA BERATURAN TAHAN GEMPA BERDASARKAN SNI 02-1726-2002 DAN FEMA 450
}

\author{
Yosafat Aji Pranata ${ }^{1}$, Calvein Haryanto ${ }^{2}$ \\ ${ }^{1}$ Dosen Jurusan Teknik Sipil, Fakultas Teknik, Universitas Kristen Maranatha \\ ${ }^{2}$ Alumnus Jurusan Teknik Sipil, Fakultas Teknik, Universitas Kristen Maranatha \\ Jalan Prof. drg. Suria Sumantri, MPH., No. 65, Bandung, 40164 \\ E-mail : yosafat.ap@eng.maranatha.edu
}

\begin{abstract}
Indonesia territory located in high risk seismic zone. Every years there are damaged buildings, died people, and other infrastructures due to earthquake occurance. The aim of this research are analysis and design of seismic resistant building of steel frame in accordance with SNI 02-1726-2002 and FEMA 450, the objectives are dimension of IWF profile for beam and column elements, base shear, displacement, connections, and foundation design. Results of this study for beam and column give same results for $\mathrm{P} / \mathrm{M}$ ratios. Relative difference between base shear $\mathrm{x}$-direction for both codes are $0.08 \%$, relative difference between base shear $y$-direction for both codes are $0.16 \%$. This difference may occurs from $\mathrm{F}_{\mathrm{xi}}$ and $\mathrm{F}_{\mathrm{yi}}$ results. Relative diffeference for $\mathrm{Vu}$ are $0.09 \%$, and $\mathrm{Mu}$ are $0.00 \%$, and $\mathrm{Nu}$ for both codes are $0,18 \%$. Results of joint reactions for both codes are approximately same. Generally, SNI 03-1726-2002 and FEMA 450 give relative difference that are not significant.
\end{abstract}

Keywords: SNI 02-1726-2002, FEMA 450, Building, Steel.

\begin{abstract}
ABSTRAK
Wilayah Indonesia mencakup daerah-daerah yang mempunyai tingkat resiko gempa yang tinggi diantara beberapa daerah gempa diseluruh dunia. Hampir setiap tahun terjadi bencana akibat gempa bumi di berbagai tempat di Indonesia. Gempa yang terjadi dapat mengakibatkan kerusakan yang menimbulkan korban jiwa serta dampaknya besar terhadap ekonomi dan pembangunan daerah di wilayah tersebut. Tujuan penelitian ini adalah melakukan perencanaan struktur gedung baja tahan gempa berdasarkan peraturan SNI 02-1726-2002 dan FEMA 450, dan pembahasan meliputi penentuan ukuran profil baja yang digunakan sebagai elemen struktur balok dan kolom, gaya geser dasar, peralihan, desain sambungan, dan perhitungan pondasi. Hasil desain balok dan kolom dengan menggunakan beban gempa berdasarkan SNI 02-1726-2002 dan FEMA 450 memberikan hasil yang sama untuk nilai rasio $\mathrm{P} / \mathrm{M}$. Nilai gaya geser nominal arah- $\mathrm{x}\left(\mathrm{V}_{\mathrm{x}}\right)$ mempunyai perbedaan sebesar $0,08 \%$, sedangkan nilai gaya geser nominal arah-y $\left(\mathrm{V}_{\mathrm{y}}\right)$ mempunyai perbedaan sebesar $0,16 \%$. Hal ini terjadi karena hasil perhitungan nilai $\mathrm{F}_{\mathrm{xi}}$ dan $\mathrm{F}_{\mathrm{yi}}$ dengan kedua metode tersebut memberikan hasil yang hampir sama. Perbedaan nilai $\mathrm{V}_{\mathrm{u}}$ pada balok sebesar $0,09 \%$, dan $\mathrm{M}_{\mathrm{u}}$ mempunyai selisih sebesar $0,00 \%$. Nilai $\mathrm{V}_{\mathrm{u}}$ dan $\mathrm{M}_{\mathrm{u}}$ pada kolom mempunyai hasil yang sama, perbedaan nilai $\mathrm{N}_{\mathrm{u}}$ sebesar $0,18 \%$. Pada reaksi tumpuan, memberikan hasil yang hampir sama, sehingga menghasilkan pondasi dan pilecap yang sama. Pada desain sambungan, baut dan pelat mempunyai hasil yang sama, hal ini dikarenakan perbedaan nilai $\mathrm{N}_{\mathrm{u}}, \mathrm{V}_{\mathrm{u}}$, dan $\mathrm{M}_{\mathrm{u}}$ berdasarkan SNI 02-1726-2002 dan FEMA 450 sangat kecil. Secara umum, metode SNI 02-1726-2002 dan FEMA 450 memberikan perbedaan hasil perhitungan yang tidak signifikan.
\end{abstract}

Kata Kunci: SNI 02-1726-2002, FEMA 450, Struktur Gedung, Baja.

\section{PENDAHULUAN}

Tingginya kerusakan karena gempa merupakan hal yang perlu ditinjau sehingga diperlukan peraturan bangunan tahan gempa. Dengan itu, kerusakan akibat gempa dapat 
diminimalkan. Peraturan bangunan tahan gempa yang berlaku saat ini yaitu Standar Perencanaan Ketahanan Gempa untuk Struktur bangunan Gedung (SNI 02-1726 - 2002) dan FEMA 450.

SNI 02-1726-2002 diterbitkan April 2002 oleh Departemen Pekerjaan Umum, merupakan pengganti dari Standar Nasional Indonesia SNI 02-1726-1989. SNI 1726 - 2002 menjadi persyaratan minimum perencanaan ketahanan gempa untuk struktur gedung. Standar ini dimaksudkan sebagai pengganti Standar Nasional Indonesia SNI 02-1726-1989 dan untuk selanjutnya menjadi persyaratan minimum perencanaan ketahanan gempa untuk struktur gedung.

Standar ini bertujuan agar struktur gedung yang ketahanan gempanya direncanakan menurut standar ini dapat berfungsi menghindari terjadinya korban jiwa manusia oleh runtuhnya gedung akibat gempa yang kuat, membatasi kerusakan gedung akibat gempa ringan sampai sedang, sehingga masih dapat diperbaiki, membatasi ketidaknyamanan penghunian bagi penghuni gedung ketika terjadi gempa ringan sampai sedang serta mempertahanakan setiap layanan vital dari fungsi gedung.

Selain tujuan fungsi diatas syarat SNI 02-1726-2002 tidak berlaku untuk bangunan seperti gedung dengan sistem struktur yang tidak umum atau yang masih memerlukan pembuktian tentang kelayakannya, gedung dengan sistem isolasi landasan (base isolation) untuk meredam pengaruh gempa terhadap struktur atas, serta rumah tinggal satu tingkat dan gedung-gedung non-teknis lainnya.

FEMA 450 diterbitkan pada tahun 2003 oleh Building Seismic Safety Council (BSSC). BSSC sendiri berdiri pada tahun 1979 dibawah bantuan National Institute of Building Sciences. FEMA 450 merupakan peraturan seismik untuk gedung baru dan struktur bangunan lain. Tujuan utama dari departemen keamanan Federal Emergency Management Agency (FEMA) dan National Earthquake Hazards Reduction Program (NEHRP) adalah untuk menganjurkan mendesain dan merencanakan suatu bangunan terhadap bahaya gempa bumi dan memperkecil resiko kerusakan dan korban jiwa. FEMA merupakan standar utama BSSC dalam perencanaan ketahanan gempa untuk struktur gedung.

Dalam penelitian ini akan dibahas tentang perbandingan peraturan gempa berdasarkan SNI 02-1726-2002 dan FEMA 450 terhadap bangunan baja. Hal yang ditinjau berupa desain balok, desain kolom, desain sambungan, serta perencanaan pondasi. 


\section{TINJAUAN LITERATUR}

\subsection{Peraturan Gempa SNI 03-1726-2002}

Struktur gedung beraturan dapat direncanakan terhadap pembebanan gempa nominal akibat pengaruh gempa rencana dalam arah masing-masing sumbu utama denah struktur tersebut, berupa beban gempa nominal statik ekuivalen.

Apabila kategori gedung memiliki faktor keutamaan I dan strukturnya untuk suatu arah sumbu utama denah struktur dan sekaligus arah pembebanan gempa rencana memiliki faktor reduksi gempa $\mathrm{R}$ dan waktu getar alami fundamental $\mathrm{T}_{1}$, maka beban geser dasar nominal statik ekuivalen $\mathrm{V}$ yang terjadi di tingkat dasar dapat dihitung menurut persamaan:

$$
\mathrm{V}=\frac{\mathrm{C}_{1} \mathrm{I}}{\mathrm{R}} \mathrm{W}_{\mathrm{t}}
$$

di mana $C_{1}$ adalah nilai faktor respons gempa yang didapat dari Spektrum Respons Gempa Rencana menurut Gambar 2.9 untuk waktu getar alami fundamental $\mathrm{T}_{1}$, sedangkan $\mathrm{W}_{\mathrm{t}}$ adalah berat total gedung, termasuk beban hidup yang sesuai.

Beban geser dasar nominal V menurut Pasal 6.1.2 harus dibagikan sepanjang tinggi struktur gedung menjadi beban-beban gempa nominal statik ekuivalen $F_{i}$ yang menangkap pada pusat massa lantai tingkat ke-i menurut persamaan:

$$
F_{i}=\frac{W_{i} z_{i}}{\sum_{i=1}^{n} W_{i} z_{i}} V
$$

di mana $\mathrm{W}_{\mathrm{i}}$ adalah berat lantai tingkat ke-i, termasuk beban hidup yang sesuai, $\mathrm{z}_{\mathrm{i}}$ adalah ketinggian lantai tingkat ke-i diukur dari taraf penjepitan lateral menurut Pasal 5.1.2 dan Pasal 5.1.3 [SNI 2002], sedangkan $\mathrm{n}$ adalah nomor lantai tingkat paling atas.

Apabila rasio antara tinggi struktur gedung dan ukuran denahnya dalam arah pembebanan gempa sama dengan atau melebihi 3, maka $0,1 \mathrm{~V}$ harus dianggap sebagai beban horisontal terpusat yang menangkap pada pusat massa lantai tingkat paling atas, sedangkan $0,9 \mathrm{~V}$ sisanya harus dibagikan sepanjang tinggi struktur gedung menjadi beban-beban gempa nominal statik ekuivalen menurut Pasal 6.1.3[SNI 2002].

\subsection{Peraturan Gempa FEMA 450}

Beban geser ditentukan dengan menggunakan analisis gaya lateral ekuivalen. Apabila kategori gedung memiliki Faktor Keutamaan I dan strukturnya untuk suatu arah sumbu utama denah struktur dan sekaligus arah pembebanan Gempa Rencana memiliki faktor 
reduksi gempa $\mathrm{R}$ dan waktu getar alami fundamental $\mathrm{T}_{1}$, maka beban geser dasar nominal statik ekuivalen $\mathrm{V}$ yang terjadi di tingkat dasar dapat dihitung menurut persamaan:

$$
\mathrm{V}=\mathrm{C}_{\mathrm{s}} \cdot \mathrm{W}_{\mathrm{t}}
$$

dimana $\mathrm{W}_{\mathrm{t}}$ adalah berat total bangunan, termasuk beban hidup yang sesuai, sedangkan $\mathrm{C}_{\mathrm{s}}$ adalah koefisien respons seismik yang didapat dari 3 persamaan yaitu:

a. $\mathrm{C}_{\mathrm{s}}=\frac{\mathrm{S}_{\mathrm{DS}}}{\left(\frac{\mathrm{R}}{\mathrm{I}}\right)}$

b. $\mathrm{C}_{\mathrm{s}}=\frac{\mathrm{S}_{\mathrm{D} 1}}{\mathrm{~T} \cdot\left(\frac{\mathrm{R}}{\mathrm{I}}\right)}$

c. $\mathrm{C}_{\mathrm{s}}=0,044 . \mathrm{I} \cdot \mathrm{S}_{\mathrm{ds}}$

dimana $\mathrm{S}_{\mathrm{DS}}$ adalah damping 5\%, parameter akselerasi respons spektral pada jangka pendek, $\mathrm{S}_{\mathrm{D} 1}$ adalah damping 5\%, parameter akselerasi respons spektral pada periode satu detik. Nilai $\mathrm{C}_{\mathrm{s}}$ yang digunakan adalah nilai yang berada diantara nilai maksimum dan nilai minimum. Beban gempa nominal statik ekuivalen di distribusikan dengan menggunakan persamaan:

$$
\mathrm{F}_{\mathrm{i}}=\mathrm{C}_{\mathrm{v}} \cdot \mathrm{V}
$$

dimana $\mathrm{C}_{\mathrm{v}}$ adalah faktor distribusi arah vertikal maupun arah horizontal. Adapun nilai $\mathrm{C}_{\mathrm{v}}$ didapatkan dari persamaan:

$$
\mathrm{C}_{\mathrm{v}}=\frac{\mathrm{W}_{\mathrm{i}} \cdot \mathrm{h}_{\mathrm{i}}}{\sum_{\mathrm{i}=1}^{n} \mathrm{~W}_{\mathrm{i}} \cdot \mathrm{h}_{\mathrm{i}}}
$$

dimana $\mathrm{W}_{\mathrm{i}}$ adalah berat lantai tingkat ke-i, termasuk beban hidup yang sesuai, $\mathrm{h}_{\mathrm{i}}$ adalah ketinggian lantai tingkat ke-i diukur dari taraf penjepitan lateral.

\subsection{Perencanaan Pondasi}

Prosedur perencanaan pondasi tiang mengikuti cara yang umum, yaitu penentuan daya dukung ujung tiang, daya dukung gesekan selimut dan daya dukung lateral. Peralihan lateral pada berbagai kombinasi beban umumnya ditentukan untuk mengetahui kemampuan tiang untuk menahan beban lateral. Masalah yang sangat 
penting dalam perencanaan adalah menentukan parameter tanah yang tepat. Dalam banyak hal, meskipun metode analisis untuk daya dukung tiang cukup banyak dan dapat memberikan jawaban yang bervariasi, tetapi kesalahan yang terjadi akibat kekeliruan parameter tanah adalah lebih fatal.

\section{STUDI KASUS DAN PEMBAHASAN}

\subsection{Data Struktur dan Diagram Alir Studi}

Data model yang digunakan adalah sebagai berikut:

$\begin{array}{ll}\text { Fungsi Bangunan } & : \text { Kantor } \\ \text { Jenis Struktur } & : \text { Baja } \\ \text { Jenis Bangunan } & : \text { Sistem Rangka Pemikul Momen Khusus (SRPMK) } \\ \text { Jenis Pondasi } & : \text { Pondasi Tiang } \\ \text { Jumlah Lantai } & : 6 \text { lantai } \\ \quad & :(18 \times 24) \mathrm{m}^{2} \\ \text { Denah gedung } & : \text { Lantai Dasar }=+0,0 \mathrm{~m} \\ \text { Tinggi Lantai } & \text { Lantai } 1=+4 \mathrm{~m} \\ & \text { Lantai } 2-6=+3,5 \mathrm{~m}\end{array}$

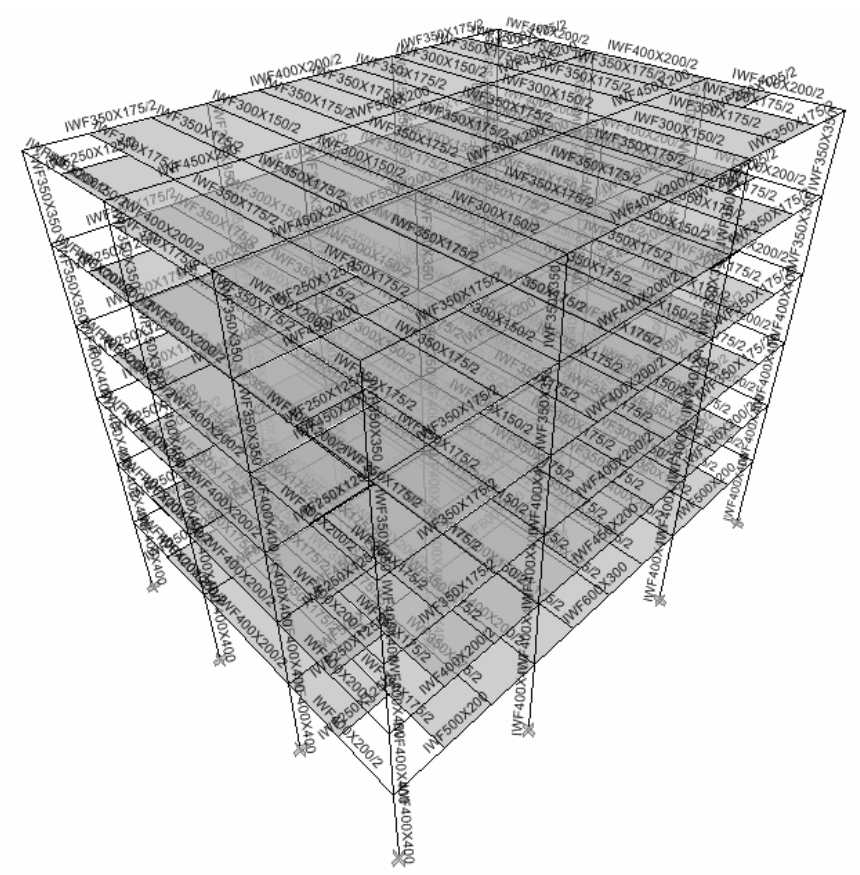

Gambar 1. Model 3D

Perencanaan Struktur Rangka Baja Beraturan Tahan Gempa Berdasarkan SNI 02-1726-2002 dan FEMA 450 


\subsubsection{Data Gedung}

Data lokasi gedung yang digunakan adalah sebagai berikut: Lokasi Bandung, Kategori Gedung Beraturan, dan Wilayah Gempa 3 jenis tanah keras.

\subsubsection{Data Material}

Komponen dari struktur gedung terdiri dari balok, kolom yang secara keseluruhan bermaterial baja dan pelat menggunakan beton dengan tebal $120 \mathrm{~mm}$. Semua komponen ini akan dimodelkan pada ETABS. Data material yang dimasukkan kedalam ETABS adalah sebagai berikut:

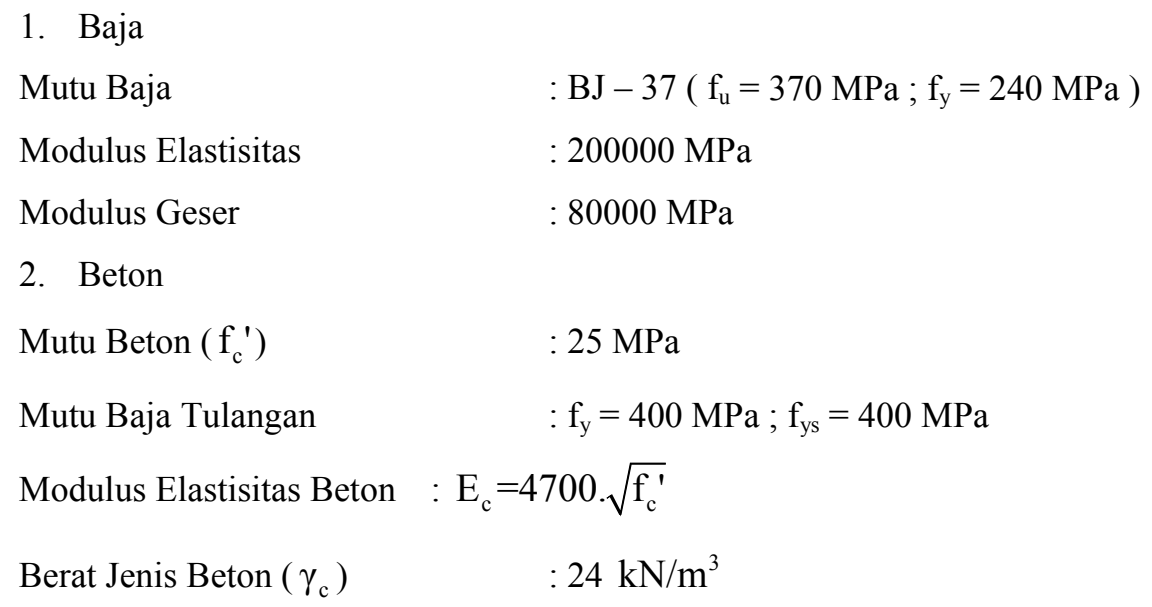

\subsubsection{Data Tanah}

Data tanah yang digunakan adalah data tanah dari pengujian sondir [Haryanto, 2009].

\subsubsection{Diagram Bagan Alir studi}

Dalam menyelesaikan permasalahan, digunakan diagram alir studi sebagai berikut: 


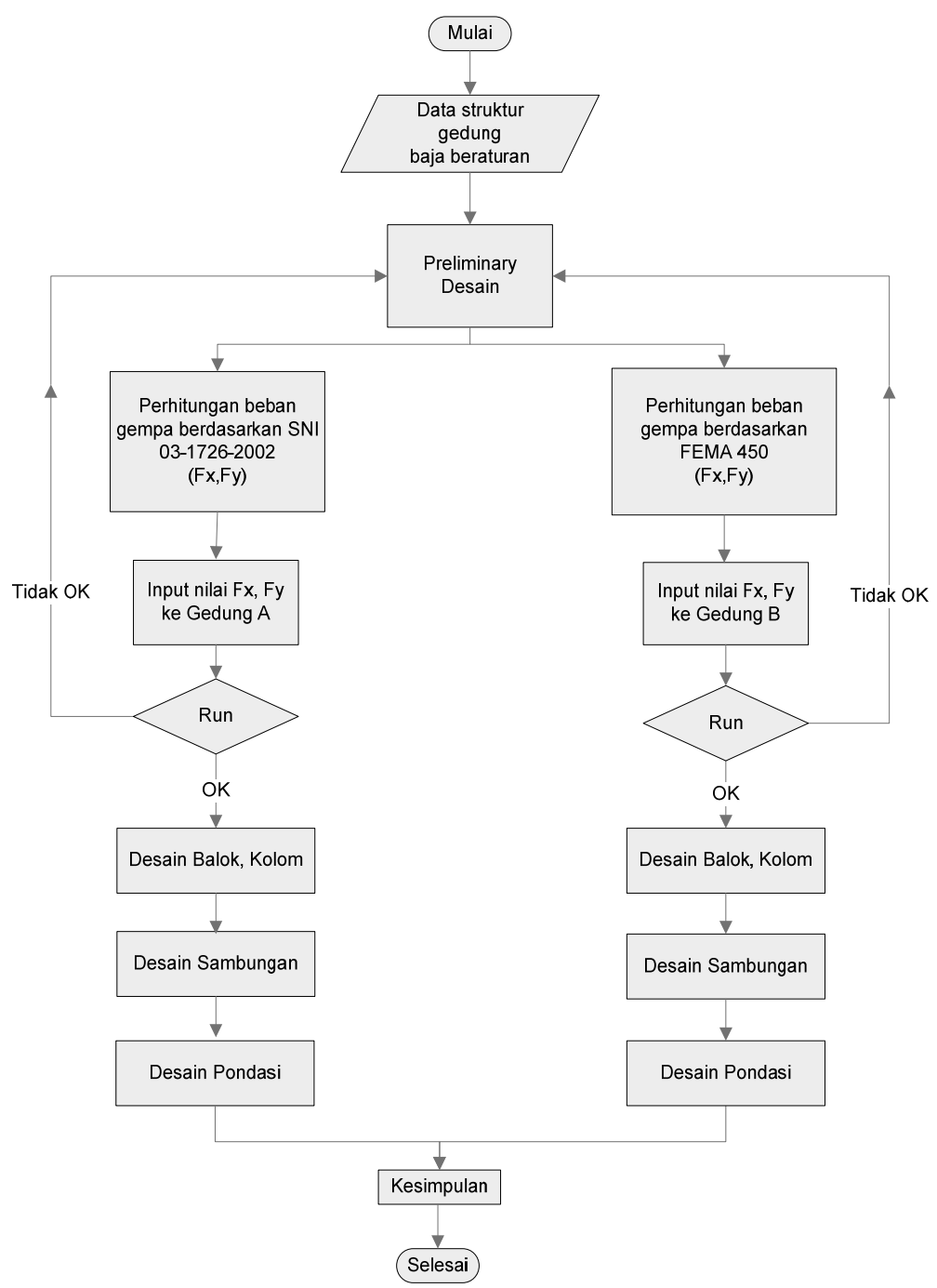

Gambar 2. Diagram Bagan Alir

3.2 Analisis Struktur Terhadap Beban Gempa Berdasarkan SNI 02-1726-2002

Tabel 1. Nilai $V_{\text {by }}$ Berdasarkan SNI 02-1726-2002, Mode 1; $T_{y}=1,0711$ detik

\begin{tabular}{|c|c|c|c|c|c|c|c|}
\hline Lantai & massa & g & Wy & $\mathrm{C}$ & I & $\mathrm{R}$ & $V_{\text {by }}$ \\
\hline 6 & 13910.66 & \multirow{6}{*}{9.81} & 136463.53 & \multirow{6}{*}{0.2147} & \multirow{6}{*}{1} & \multirow{6}{*}{8.5} & \multirow{6}{*}{21498.28} \\
\hline 5 & 14307.70 & & 140358.50 & & & & \\
\hline 4 & 14392.04 & & 141185.88 & & & & \\
\hline 3 & 14500.49 & & 142249.85 & & & & \\
\hline 2 & 14556.31 & & 142797.38 & & & & \\
\hline 1 & 15093.20 & & 148064.28 & & & & \\
\hline
\end{tabular}

Perencanaan Struktur Rangka Baja Beraturan Tahan Gempa Berdasarkan SNI 02-1726-2002 dan FEMA 450 
Tabel 2. Nilai $V_{b x}$ Berdasarkan SNI 02-1726-2002, Mode 2; $T_{x}=0,9813$ detik

\begin{tabular}{|c|c|c|c|c|c|c|c|}
\hline Lantai & massa & g & Wx & $\mathrm{C}$ & I & $\mathrm{R}$ & $\mathrm{V}_{\mathrm{bx}}$ \\
\hline 6 & 13910.66 & \multirow{6}{*}{9.81} & 136463.53 & \multirow{6}{*}{0.2344} & \multirow{6}{*}{1} & \multirow{6}{*}{8.5} & \multirow{6}{*}{23470.87} \\
\hline 5 & 14307.70 & & 140358.50 & & & & \\
\hline 4 & 14392.04 & & 141185.88 & & & & \\
\hline 3 & 14500.49 & & 142249.85 & & & & \\
\hline 2 & 14556.31 & & 142797.38 & & & & \\
\hline 1 & 15093.20 & & 148064.28 & & & & \\
\hline
\end{tabular}

Tabel 3. Nilai $F_{y}$ Berdasarkan SNI 02-1726-2002, $T_{y}=1,0711$ detik; $V_{b y}=21498,28$

\begin{tabular}{|c|c|c|c|c|c|c|c|}
\hline Lantai & massa & $\mathrm{g}$ & Wy & hy & Wy.hy & $F_{y}$ & $V_{y}$ \\
\hline 6 & 13910.66 & \multirow{6}{*}{9.81} & 136463.53 & 21.50 & 2933965.93 & 5875.33 & 5875.33 \\
\hline 5 & 14307.70 & & 140358.50 & 18.00 & 2526453.07 & 5059.28 & 10934.61 \\
\hline 4 & 14392.04 & & 141185.88 & 14.50 & 2047195.26 & 4099.55 & 15034.17 \\
\hline 3 & 14500.49 & & 142249.85 & 11.00 & 1564748.36 & 3133.44 & 18167.61 \\
\hline 2 & 14556.31 & & 142797.38 & 7.50 & 1070980.33 & 2144.66 & 20312.27 \\
\hline 1 & 15093.20 & & 148064.28 & 4.00 & 592257.12 & 1186.01 & 21498.28 \\
\hline
\end{tabular}

Tabel 4. Nilai $F_{x}$ Berdasarkan SNI 02-1726-2002, $T_{x}=0$,9813 detik; $V_{b x}=23470,87$

\begin{tabular}{|c|c|c|c|c|c|c|c|}
\hline Lantai & massa & $\mathrm{g}$ & $\mathrm{Wx}$ & $\mathrm{hx}$ & Wx.hx & $\mathrm{F}_{\mathrm{x}}$ & $\mathrm{Vx}$ \\
\hline 6 & 13910.66 & \multirow{6}{*}{9.81} & 136463.53 & 21.50 & 2933965.93 & 6414.43 & 6414.43 \\
\hline 5 & 14307.70 & & 140358.50 & 18.00 & 2526453.07 & 5523.50 & 11937.92 \\
\hline 4 & 14392.04 & & 141185.88 & 14.50 & 2047195.26 & 4475.71 & 16413.64 \\
\hline 3 & 14500.49 & & 142249.85 & 11.00 & 1564748.36 & 3420.96 & 19834.59 \\
\hline 2 & 14556.31 & & 142797.38 & 7.50 & 1070980.33 & 2341.45 & 22176.04 \\
\hline 1 & 15093.20 & & 148064.28 & 4.00 & 592257.12 & 1294.83 & 23470.87 \\
\hline
\end{tabular}

\subsection{Analisis Struktur Terhadap Beban Gempa Berdasarkan FEMA 450}

Tabel 5. Nilai F $_{\mathbf{y}}$ Berdasarkan FEMA 450

\begin{tabular}{|c|c|c|c|c|c|c|c|c|}
\hline Lantai & massa & $\mathrm{g}$ & $\mathrm{Wi}$ & hi & Wi.hi & Cvy & Fy & Vy \\
\hline 6 & 13910.66 & \multirow{6}{*}{9.81} & 136463.53 & 21.50 & 2933965.93 & 0.27 & 5884.91 & 5884.91 \\
\hline 5 & 14307.70 & & 140358.50 & 18.00 & 2526453.07 & 0.24 & 5067.53 & 10952.43 \\
\hline 4 & 14392.04 & & 141185.88 & 14.50 & 2047195.26 & 0.19 & 4106.24 & 15058.67 \\
\hline 3 & 14500.49 & & 142249.85 & 11.00 & 1564748.36 & 0.15 & 3138.55 & 18197.22 \\
\hline 2 & 14556.31 & & 142797.38 & 7.50 & 1070980.33 & 0.10 & 2148.16 & 20345.38 \\
\hline 1 & 15093.20 & & 148064.28 & 4.00 & 592257.12 & 0.06 & 1187.94 & 21533.32 \\
\hline
\end{tabular}


Tabel 6. Nilai $F_{x}$ Berdasarkan FEMA 450

\begin{tabular}{|c|c|c|c|c|c|c|c|c|}
\hline Lantai & massa & $\mathrm{g}$ & Wi & hi & Wi.hi & Cvx & Fx & $\mathrm{Vx}$ \\
\hline 6 & 13910.66 & \multirow{6}{*}{9.81} & 136463.53 & 21.50 & 2933965.93 & 0.27 & 6419.90 & 6419.90 \\
\hline 5 & 14307.70 & & 140358.50 & 18.00 & 2526453.07 & 0.24 & 5528.21 & 11948.11 \\
\hline 4 & 14392.04 & & 141185.88 & 14.50 & 2047195.26 & 0.19 & 4479.53 & 16427.64 \\
\hline 3 & 14500.49 & & 142249.85 & 11.00 & 1564748.36 & 0.15 & 3423.87 & 19851.52 \\
\hline 2 & 14556.31 & & 142797.38 & 7.50 & 1070980.33 & 0.10 & 2343.44 & 22194.96 \\
\hline 1 & 15093.20 & & 148064.28 & 4.00 & 592257.12 & 0.06 & 1295.94 & 23490.90 \\
\hline
\end{tabular}

\subsection{Desain Sambungan}

\subsubsection{Sambungan Kolom dengan Balok}

Hasil perencanaan sambungan kolom dengan balok ditampilkan pada Gambar 3 . Perhitungan selengkapnya dapat dilihat pada penelitian Haryanto [Haryanto, 2009].
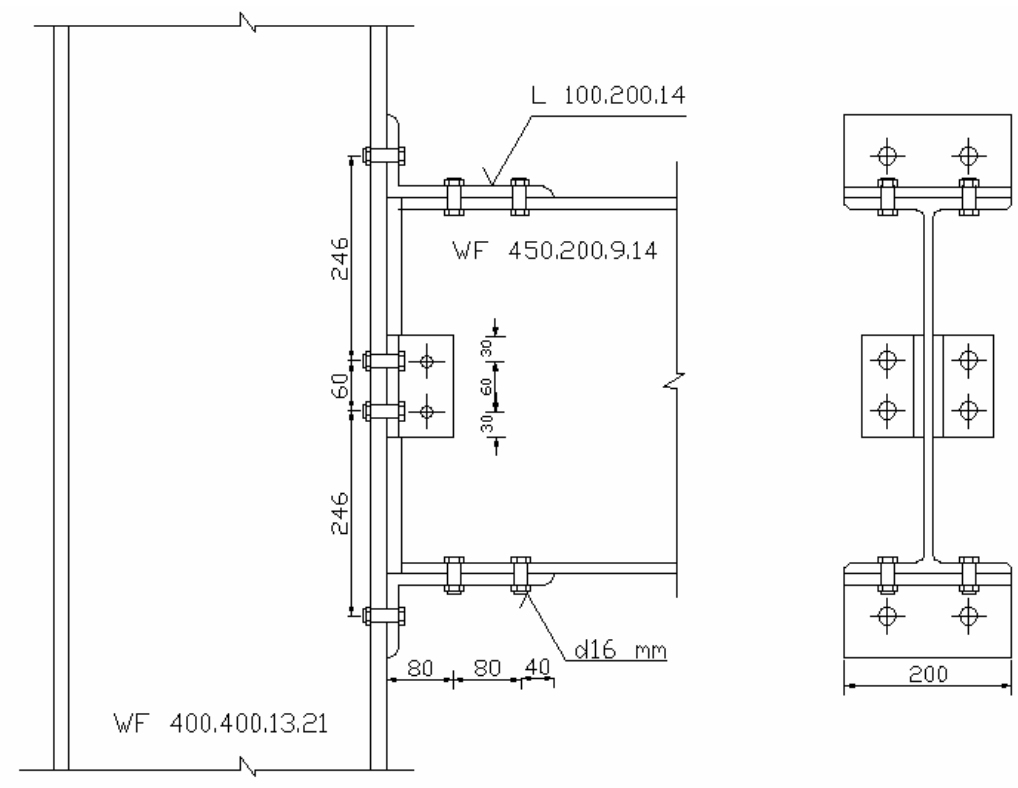

Gambar 3. Detail Sambungan Balok-Kolom

\subsubsection{Sambungan Kolom dengan Kolom}

Hasil perencanaan sambungan kolom dengan kolom ditampilkan pada Gambar 4. Perhitungan selengkapnya dapat dilihat pada penelitian Haryanto [Haryanto, 2009]. 

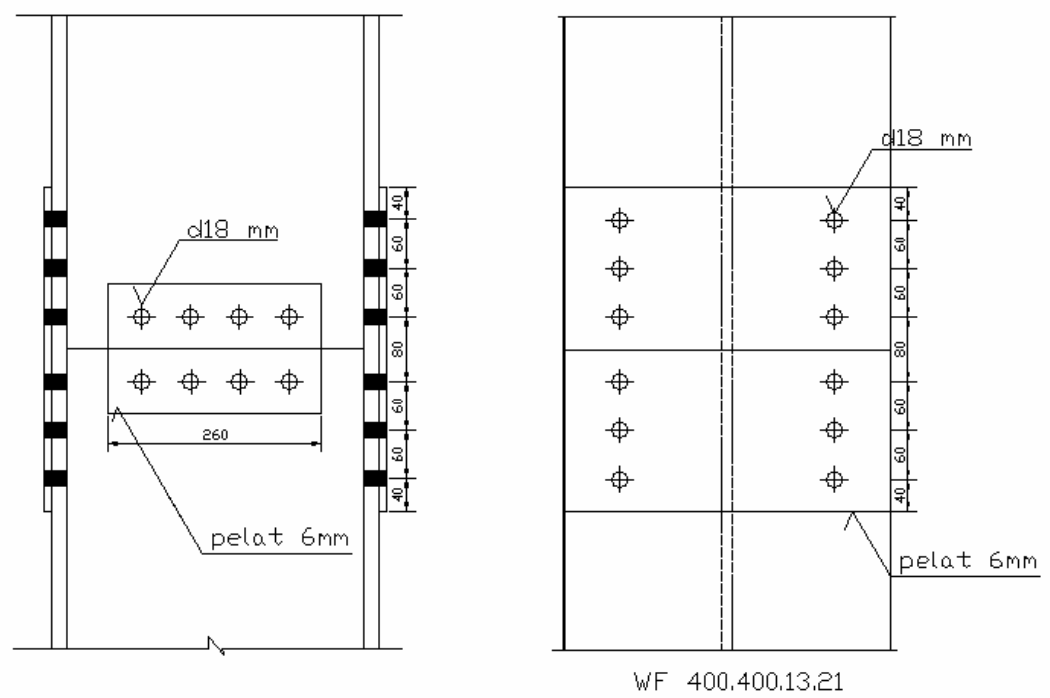

\section{Gambar 4. Detail Sambungan Kolom-Kolom}

\subsubsection{Sambungan Balok Induk dengan Balok Anak}

Hasil perencanaan sambungan balok induk dengan balok anak ditampilkan pada Gambar 3. Perhitungan selengkapnya dapat dilihat pada penelitian Haryanto [Haryanto, 2009].

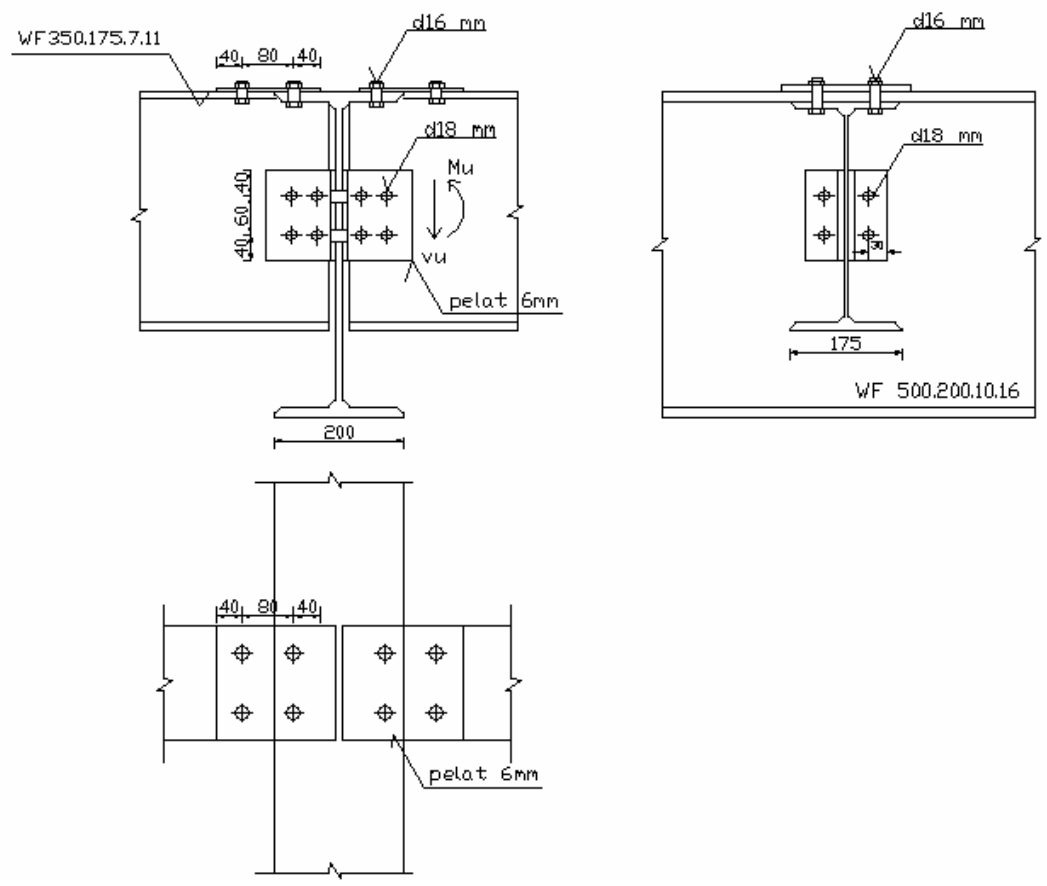

Gambar 5. Detail Sambungan Balok Induk-Balok Anak 


\subsubsection{Sambungan Kolom dengan Perletakan}

Hasil perencanaan sambungan kolom dengan perletakan ditampilkan pada Gambar 6. Perhitungan selengkapnya dapat dilihat pada penelitian Haryanto [Haryanto, 2009].
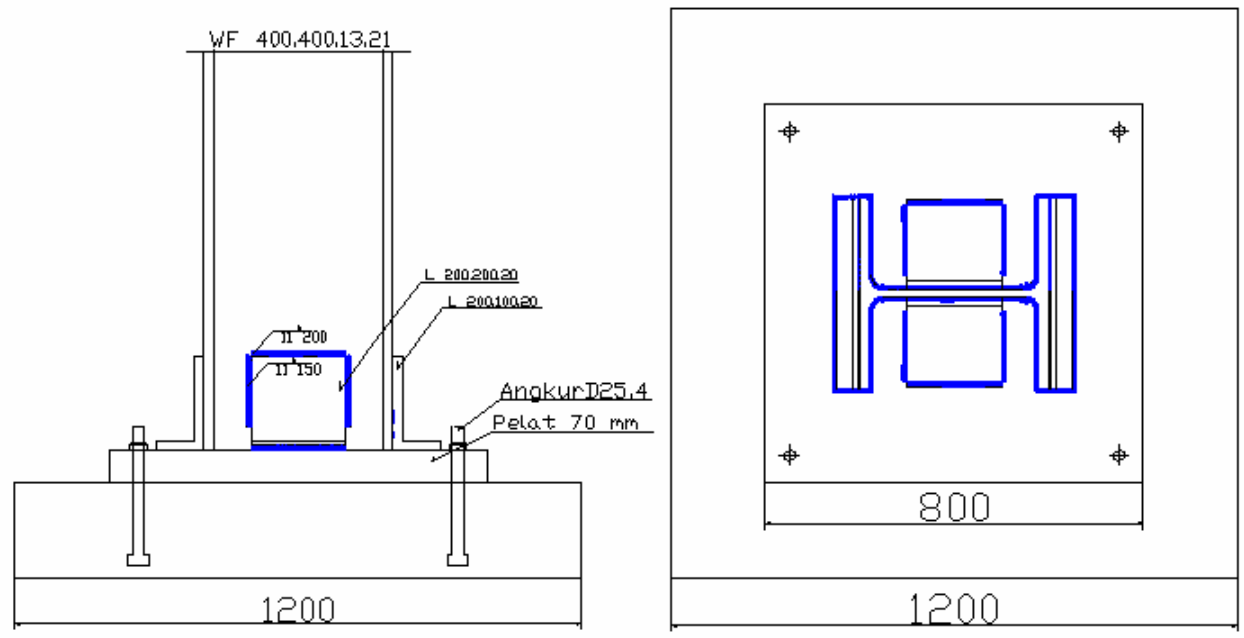

Gambar 6. Detail Sambungan Kolom-Perletakan

\subsection{Perencanaan Pondasi}

Hasil perencanaan pondasi ditampilkan pada Gambar 7. Perhitungan selengkapnya dapat dilihat pada penelitian Haryanto [Haryanto, 2009].
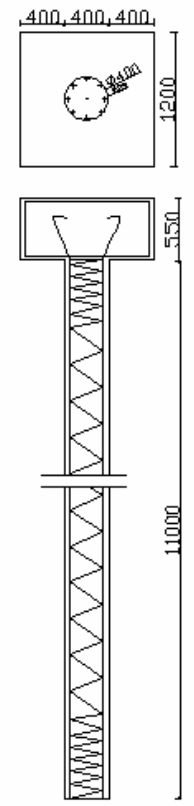

Gambar 7. Detail Pondasi yang Didesain Berdasarkan SNI 02-1726-2002

Perencanaan Struktur Rangka Baja Beraturan Tahan Gempa Berdasarkan SNI 02-1726-2002 dan FEMA 450 


\section{PEMBAHASAN}

Pembahasan hasil penelitian selanjutnya ditampilkan pada Tabel 7 sampai dengan

Tabel 16

Tabel 7. Perbandingan Nilai $F_{x}$

\begin{tabular}{|c|c|c|c|}
\hline $\mathrm{F}_{\mathrm{x}}$ & $\begin{array}{c}\text { SNI 02-1726-2002 } \\
(\mathrm{kg})\end{array}$ & $\begin{array}{c}\text { FEMA 450 } \\
(\mathrm{kg})\end{array}$ & $\%$ beda \\
\hline 6 & 6414.43 & 6419.90 & $0,08 \%$ \\
\hline 5 & 5523.50 & 5528.21 & $0,08 \%$ \\
\hline 4 & 4475.71 & 4479.53 & $0,08 \%$ \\
\hline 3 & 3420.96 & 3423.87 & $0,08 \%$ \\
\hline 2 & 2341.45 & 2343.44 & $0,08 \%$ \\
\hline 1 & 1294.83 & 1295.94 & $0,08 \%$ \\
\hline $\mathrm{V}_{\mathrm{x}}$ & 23470.87 & 23490.90 & $0,08 \%$ \\
\hline
\end{tabular}

Tabel 8. Perbandingan Nilai $\mathrm{F}_{\mathrm{y}}$

\begin{tabular}{|c|c|c|c|}
\hline $\mathrm{F}_{\mathrm{y}}$ & $\begin{array}{c}\text { SNI 02-1726-2002 } \\
(\mathrm{kg})\end{array}$ & $\begin{array}{c}\text { FEMA 450 } \\
(\mathrm{kg})\end{array}$ & \% beda \\
\hline 6 & 5875.33 & 5884.91 & $0,16 \%$ \\
\hline 5 & 5059.28 & 5067.53 & $0,16 \%$ \\
\hline 4 & 4099.55 & 4106.24 & $0,16 \%$ \\
\hline 3 & 3133.44 & 3138.55 & $0,16 \%$ \\
\hline 2 & 2144.66 & 2148.16 & $0,16 \%$ \\
\hline 1 & 1186.01 & 1187.94 & $0,16 \%$ \\
\hline $\mathrm{V}_{\mathrm{y}}$ & 21498.28 & 21533.32 & $0,16 \%$ \\
\hline
\end{tabular}

Tabel 9. Gaya-gaya Dalam dan Lendutan

\begin{tabular}{|c|c|c|c|}
\hline & $\begin{array}{c}\text { SNI 02-1726-2002 } \\
(\mathrm{N}-\mathrm{mm})\end{array}$ & $\begin{array}{c}\text { FEMA 450 } \\
(\mathrm{N}-\mathrm{mm})\end{array}$ & \% beda \\
\hline $\mathrm{N}_{\mathrm{u}}$ & 0 & 0 & $0 \%$ \\
\hline $\mathrm{V}_{\mathrm{u}}$ & 3279,54 & 3282,73 & $0,09 \%$ \\
\hline $\mathrm{M}_{\mathrm{u}}$ & 7243461,697 & 7253024,32 & $0,13 \%$ \\
\hline Lendutan & 0,738 & 0,738 & $0 \%$ \\
\hline
\end{tabular}


Tabel 10. Gaya Dalam Pada Kolom

\begin{tabular}{|c|c|c|c|}
\hline & $\begin{array}{c}\text { SNI 02-1726-2002 } \\
(\mathrm{N}-\mathrm{mm})\end{array}$ & $\begin{array}{c}\text { FEMA 450 } \\
(\mathrm{N}-\mathrm{mm})\end{array}$ & \% beda \\
\hline $\mathrm{N}_{\mathrm{u}}$ & 2441061,3 & 2445642,9 & $0,18 \%$ \\
\hline $\mathrm{V}_{\mathrm{u}}$ & 11020,21 & 11020,21 & $0 \%$ \\
\hline $\mathrm{M}_{\mathrm{u}}$ & 20154851,7 & 20154851,7 & $0 \%$ \\
\hline
\end{tabular}

Tabel 11. Reaksi Tumpuan

\begin{tabular}{|c|c|c|c|}
\hline & $\begin{array}{c}\text { SNI 02-1726-2002 } \\
(\mathrm{kg}-\mathrm{m})\end{array}$ & $\begin{array}{c}\text { FEMA 450 } \\
(\mathrm{kg}-\mathrm{m})\end{array}$ & \% beda \\
\hline $\mathrm{N}_{\mathrm{u}}$ & 154901,13 & 154902,78 & $0,001 \%$ \\
\hline $\mathrm{V}_{\mathrm{u}}$ & 2205,02 & 2206,85 & $0,08 \%$ \\
\hline $\mathrm{M}_{\mathrm{u}}$ & 5367,851 & 5372,41 & $0,08 \%$ \\
\hline
\end{tabular}

Tabel 12. Perbedaan Desain Sambungan Balok-Kolom

\begin{tabular}{|c|c|c|c|}
\hline & SNI 02-1726-2002 & FEMA 450 & \% beda \\
\hline Baut pada Badan & 2 & 2 & $0 \%$ \\
\hline Baut pada sayap & 4 & 4 & $0 \%$ \\
\hline Pelat pada badan & Siku 100.200.14 & Siku 100.200.14 & $0 \%$ \\
\hline Pelat pada sayap & Siku 100.200.14 & Siku 100.200.14 & $0 \%$ \\
\hline
\end{tabular}

Tabel 13. Perbedaan Desain Sambungan Kolom-Kolom

\begin{tabular}{|c|c|c|c|}
\hline & SNI 02-1726-2002 & FEMA 450 & \% beda \\
\hline Baut pada Badan & 4 & 4 & $0 \%$ \\
\hline Baut pada sayap & 6 & 6 & $0 \%$ \\
\hline Pelat pada badan & $6 \mathrm{~mm}$ & $6 \mathrm{~mm}$ & $0 \%$ \\
\hline Pelat pada sayap & $6 \mathrm{~mm}$ & $6 \mathrm{~mm}$ & $0 \%$ \\
\hline
\end{tabular}

Tabel 14. Perbedaan Desain sambungan Balok Induk-Balok Anak

\begin{tabular}{|c|c|c|c|}
\hline & SNI 02-1726-2002 & FEMA 450 & \% beda \\
\hline Baut pada Badan & 4 & 4 & $0 \%$ \\
\hline Baut pada sayap & 4 & 4 & $0 \%$ \\
\hline Pelat pada badan & $6 \mathrm{~mm}$ & $6 \mathrm{~mm}$ & $0 \%$ \\
\hline Pelat pada sayap & $6 \mathrm{~mm}$ & $6 \mathrm{~mm}$ & $0 \%$ \\
\hline
\end{tabular}


Tabel 15. Perbedaan Desain sambungan Kolom-Perletakan

\begin{tabular}{|c|c|c|c|}
\hline & SNI 02-1726-2002 & FEMA 450 & \% beda \\
\hline Base Plate & 800.800 & 800.800 & $0 \%$ \\
\hline Pier & 1200.1200 & 1200.1200 & $0 \%$ \\
\hline Tebal Base Plate & $70 \mathrm{~mm}$ & $70 \mathrm{~mm}$ & $0 \%$ \\
\hline Panjang Angkur & $300 \mathrm{~mm}$ & $300 \mathrm{~mm}$ & $0 \%$ \\
\hline
\end{tabular}

Tabel 16. Pondasi dan Pilecap

\begin{tabular}{|c|c|c|c|}
\hline & SNI 02-1726-2002 & FEMA 450 & $\%$ beda \\
\hline $\mathrm{N}_{\mathrm{u}}$ & $154901,13 \mathrm{~kg}$ & $154902,78 \mathrm{~kg}$ & $0,001 \%$ \\
\hline Panjang Tiang (L) & $1100 \mathrm{~cm}$ & $1100 \mathrm{~cm}$ & $0 \%$ \\
\hline Diameter Tiang (D) & $40 \mathrm{~cm}$ & $40 \mathrm{~cm}$ & $0 \%$ \\
\hline Tebal Pilecap & $55 \mathrm{~cm}$ & $55 \mathrm{~cm}$ & $0 \%$ \\
\hline Panjang Pilecap & $120 \mathrm{~cm}$ & $120 \mathrm{~cm}$ & $0 \%$ \\
\hline Deflection & $0,3 \mathrm{~cm}$ & $0,3 \mathrm{~cm}$ & $0 \%$ \\
\hline
\end{tabular}

\section{KESIMPULAN}

Berdasarkan hasil analisis dapat ditarik beberapa kesimpulan, yaitu:

1. Hasil desain balok dan kolom dengan menggunakan beban gempa berdasarkan SNI 021726-2002 dan FEMA 450 memberikan hasil yang sama untuk nilai rasio P/M.

2. Nilai gaya geser nominal arah-x $\left(\mathrm{V}_{\mathrm{x}}\right)$ berdasarkan SNI 02-1726-2002 dan FEMA 450 mempunyai perbedaan sebesar $0,08 \%$, sedangkan nilai gaya geser nominal arah-y $\left(\mathrm{V}_{\mathrm{y}}\right)$ berdasarkan SNI 02-1726-2002 dan FEMA 450 mempunyai perbedaan sebesar 0,16\%. Hal ini terjadi karena hasil perhitungan nilai $\mathrm{F}_{\mathrm{xi}}$ dan $\mathrm{F}_{\mathrm{yi}}$ dengan kedua metode tersebut memberikan hasil yang hampir sama.

3. Pada balok yang ditinjau, perbedaan nilai $\mathrm{V}_{\mathrm{u}}$ pada gedung yang didesain dengan SNI 02-1726-2002 dan FEMA 450 sebesar 0,09\%, dan $M_{u}$ mempunyai selisih sebesar $0,13 \%$. Sedangkan lendutan pada balok perbedaan $0,00 \%$.

4. Pada kolom yang ditinjau, nilai $\mathrm{V}_{\mathrm{u}}$ dan $\mathrm{M}_{\mathrm{u}}$ pada gedung yang didesain dengan SNI 021726-2002 dan FEMA 450 mempunyai hasil yang sama, perbedaan nilai $\mathrm{N}_{\mathrm{u}}$ sebesar $0,18 \%$.

5. Pada reaksi tumpuan, perbedaan nilai $\mathrm{N}_{\mathrm{u}}$ adalah $0,001 \%$, nilai $\mathrm{V}_{\mathrm{u}}$ mempunyai perbedaan $0,08 \%$ sedangkan perbedaan pada $\mathrm{M}_{\mathrm{u}}$ adalah $0,08 \%$, sehingga menghasilkan pondasi 
tiang dan ukuran pilecap yang sama pada gedung yang didesain dengan SNI 02-17262002 dengan gedung yang didesain dengan FEMA 450.

6. Pada desain sambungan, baut dan pelat mempunyai hasil yang sama, hal ini dikarenakan perbedaan nilai $\mathrm{N}_{\mathrm{u}}, \mathrm{V}_{\mathrm{u}}$, dan $\mathrm{M}_{\mathrm{u}}$ berdasarkan gedung yang didesain dengan SNI 02-1726-2002 dan FEMA 450 sangat kecil.

7. Pada desain pondasi akibat beban lateral didapatkan nilai displacement sebesar $3 \mathrm{~mm}$.

8. Secara umum, Metode SNI 02-1726-2002 dan metode FEMA 450 memberikan perbedaan hasil perhitungan yang tidak terlalu signifikan. Hal ini mengindikasikan bahwa dalam hal studi kasus ini, peraturan gempa Indonesia memberikan hasil rekomendasi yang tidak berbeda dengan peraturan gempa Amerika Serikat. Hal ini dapat terjadi dikarenakan nilai gaya geser dasar (V) dari hasil perhitungan tersebut hampir sama.

\section{DAFTAR PUSTAKA}

1. Badan Standardisasi Nasional, 2002, Standar Perencanaan Ketahanan Gempa Untuk Struktur Bangunan Gedung (SN1 02-1726-2002).

2. Badan Standardisasi Nasional, 2002, Tata Cara Perhitungan Struktur Baja Untuk Bangunan Gedung (SN1 03-1729-2002).

3. Badan Standardisasi Nasional, 2002, Tata Cara Perhitungan Struktur Beton Untuk Bangunan Gedung (SN1 03-2847-2002).

4. Bowles, J.E, 1993, Analisis Dan Desain Pondasi Edisi Keempat, Penerbit Erlangga.

5. Computer and Structures, Inc. 2007, "ETABS version 9.5.0", Computer and Structures, Inc., Berkeley, C.A.

6. Engineering Service Center, 1999, Daftar Produk Baja PT.Gunung Garuda.

7. ENSOFT, Incorporated 2003, LPILEPlus version 4.0, produksi Ensoft Inc.

8. Haryanto, C. 2009. Tugas Akhir, Jurusan Teknik Sipil, Fakultas Teknik, Universitas Kristen Maranatha.

9. Madutujuh, N. 1999, Concrete Pilecap Design, Produksi PT. Anugrah Multi Cipta Karya.

10.Peraturan Gempa FEMA 450, 2004, Recommended Provisions For Seismic Regulations For New Buildings And Other Structures (FEMA 450).

11.RISA Technologies1999, RISABase version 1.02, produksi RISA Technologies.

12.Salmon, C.G \& Johnson, J.E, 1990, Struktur Baja 2, Terjemahan Penerbit Gramedia.

Perencanaan Struktur Rangka Baja Beraturan Tahan Gempa Berdasarkan SNI 02-1726-2002 dan FEMA 450 